Бојан Ђорђевић

Универзитет у Београду

Филолошки факултет
001.32(497.1):929 Андрић И. https://doi.org/10.18485/ai_lik.2018.4.6.1 оригинални научни рад

\title{
ИВО АНДРИЋ У САВЕТУ АКАДЕМИЈА ФЕДЕРАТИВНЕ НАРОДНЕ РЕПУБЛИКЕ ЈУГОСЛАВИЈЕ
}

У раду се анализира деловање Ива Андрића у Савету академија Федеративне народне републике Југославије, од 1948. до 1959. године. Указује се на теме које су заокупљале његову пажњу и на његове ставове о раду самога Савета академија, о сталешком положају академика, односу науке и уметности у југословенским академијама, као и о другим питањима, попут језика, друштвене одговорности интелектуалаца, и слично.

Кључне речи: Иво Андрић, Савет академија, академици, наука, култура, уметност, сарадња.

У годинама непосредно после Другог светског рата, у раном периоду социјалистичке Југославије, са централистичким тенденцијама, југословенски политички врх, тачније онај његов део задужен за просвету и културу, показивао је жељу за стварањем централних југословенских институција културе и науке. Неке од тих институција - попут Југословенског драмског позоришта или Архива Југославије - успешно су радиле, а делују и данас у измењеним условима. Но, друге се нису одржале и гасиле су се пре или касније, не успевши да надживе државу у којој су настале. Тако се, рецимо, Државна централна библиотека, основана још 1945. године, тихо угасила после само пет година, а да, право говорећи, није озбиљно ни отпочела да функционише, нити да оствари ниједан од задатака који су јој били намењени. ${ }^{1}$

nalesko1965@gmail.com

1 Видети: Бојан Ђорђевић, „Државна централна библиотека Југославије: један неуспео подухват“, Библиотекар, 2017, LIX, 2, 91-100. 
У таквој атмосфери јавила се и идеја о обједињавању рада трију постојећих академија наука - Југославенске академије знаности и умјетности, Српске академије наука и Академије знаности ин уметности Словеније. Тако је створен Југословенски академски савет, који ће нешто касиије добити назив Савет академија Федеративне народне републике Југославије (доцније Социјалистичке федеративне републике Југославије), у коме ће више од деценије значајну улогу играти Иво Андрић. Да је у почетку доминирала идеја да овај Савет заправо буде нуклеус будуће заједничке југословенске академије сведочи дискусија на првом скупу Савета, одржаном 17. и 18. новембра 1948. године у Београду (пре тога одржан је, 10. и 11. јануара 1948. године, састанак представника трију академија наука у Загребу, на коме је Југословенски академски савет званично формиран). ${ }^{2}$ Већ на том првом скупу, већина делегата изразила је противљење стварању државне централне академије, упркос изричитом ставу представника државе, Родољуба Чолаковића, да „Савет треба да буде језгро будуће Савезне академије наука“. Овај став подржао је само Иво Андрић, истичући да аутономија постојећих академија додуше не сме бити доведена у питање, али стајући на становиште да јединствена држава мора да има своју академију: „Не иде се за неким механичким уједињавањем свега тога; иде се за тим да се од те три академије створи нешто четврто, што би било нама свима заједничко. Не можемо негирати да постоје државне академије, али постоји и ФНРЈ, која је једна велика животна и политичка реалност, којој би требало да послужимо“. је, очигледно, пресудно за овакво залагање. Као што се у то време здушно залагао за јачање улоге Савеза књижевника Југославије у односу на републичке књижевне организације, тако је поступао и у случају међуакадемијских релација. Но,

2 Архив Југославије /даље: АЈ/ 55-1-1 (10. и 11. јануар 1948). У име САН делегати су били Александар Белић, Војислав Мишковић, Петар Колендић, Павле Савић и Петар Јовановић, у име АЗУС Леонид Питамиц, Јован Хаџи и Милко Кос, а у име ЈАЗУ Андрија Штампар, Мирослав Крлежа, Бранимир Гушић, Марко Костренчић и Вале Воук. АЈ 55-2-14 (17. и 18. новембар 1948). 
словеначки и хрватски, али и већина српских представника у Савету академија, били су, међутим, против тога да Савет академија прерасте у савезну академију, истичући да треба да има само посредничку и надзорну улогу. И заиста се од идеје о стварању савезне академије одустало, умногоме и због отпочелог процеса децентрализације, изазваног Резолуцијом Информбироа и сукобом са СССР. Занимљиво је да је - према сведочењу Синише Станковића на једном скупу Савета академија одржаном 1953. године - идеја да се формира савезна академија наука била записана и у резолуцији историјског Петог конгреса КПЈ, али „развитак нашег живота није могао бити упућен на то да се створи на силу једно централно научно тело које би на себе примило улогу и функцију једне савезне академије“. Ипак, Иво Андрић се доследно залагао за јачање надлежности Савета академија. Када су, због рационалности и уштеде средстава, а и због децентрализације, стали да се гасе поједини институти широм земље, Андрић је указивао на опасност да се тиме прекину већ отпочети научни и културни послови, и залагао се да се они пребаце у надлежност Савета академија, који би те задатке, потом, поверио другим установама. ${ }^{5}$

Из ових разлога, делатност Савета академија никада није била до краја дефинисана. Најопштије - а уједно и најнеухватљивије - било је одређење ове институције као „саветодавног тела које координира рад трију академија“. одређење с једне стране није на прави начин одсликавало ингеренције које је Савет имао. Рецимо, Савет је искључиво располагао новцем који је за научни рад додељивала Федерација и распоређивао га националним академијама наука. Расправе о финансијским питањима биле су врло жустре, јер се радило о знатним средствима, док су републички буџети Србије, Хрватске и Словеније опредељивали врло мало новца за рад својих академија. Андрић је, када је о новцу био реч, имао врло рационалан, изразито прагматичан приступ. Истицао је да се Савет академија не може

АJ 55-5-28 (20. и 21. фебруар 1953).

АЈ 55-5-27 (19. и 20. децембар 1952).

АЈ 55-4-23 (29. и 30. октобар 1951). 
бавити само историјским и теоријским промишљањима (која су, заправо, била предмет рада појединачних академија), већ да својим научним и стручним капацитетом мора помоћи решавању горућих државних проблема важних за опстанак и развој земље, „поготово у овом тренутку“ (мислећи, наравно, на сукоб са Информбироом и изолацију):

Мислим да би могло допринети објашњењу ствари ако кажем још и ово. Историски или етнографски споменици, и они несумњиво да су предмет бриге Савета и да треба да им приступимо. Али има предмета који су хитнији и нови, а који скоро нису ни рађени. На пример питања исхране, огрева и одела, која нам се намећу као врло важна у вези са политичкокултурним развијањем. Несумњиво да ће требати повезати изоловане раднике на овим питањима, координирати акције, итд. Само толико, да би и то морало бити предмет интересовања Савета и једна конкретна услуга држави и друштву. ${ }^{7}$

Но, Андрић је исто такав - скроман, рационалан и штедљив - био и када су у питању били хонорари за чланове Савета академија. Наиме, на предлог да се, због повећања пореза, повећају и хонорари члановима Савета, Андрић се оштро успротивио, истичући да тај захтев „изазива мучан утисак“ и да се на тај начин „изиграва држава“, што је, по његовом мишљењу, било недопустиво. Занимљиво је да је Андрића одлучно подржао Мирослав Крлежа, који је, полемишући са Јосипом Видмаром, директно тврдио да је Андрић у праву, а да „неки чланови овога Савета имају пиљарску психологију“. Савет је, на крају, стао на Андрићево и Крлежино становиште, а Видмар је остао усамљен. ${ }^{8}$

Други пут, пак, Андрић се чудио што се исплаћују дневнице члановима Савета академија чак и онда када се састанци Савета одржавају у њиховом граду. ${ }^{9}$ У складу са тим, кад год се седница Савета одржавала у Београду, Андрић се одрицао дневнице.

У том смислу, Андрић је позивао и на много рационалнији приступ организовању разних научних конгреса у Југославији. Иако је и на тај начин земља полако излазила

7 АJ 55-2-14 (17. и 18. новембар 1948).

8 AJ 55-8-43 (4. јануар 1958).

9 АJ 55-5-30 (27. новембар 1953). 
из изолације и настојала да ухвати прикључак пре свега са Западом (што је, наравно, имало за последицу и одређен степен демократизације у науци и култури), упозоравао је Андрић на олако трошење новца на организацију разних конгреса, а без контроле и одобрења Савета академија:

Наши људи сазивају веће или мање састанке у нашој земљи по једној линији која је неразумљива. Не ради се само о питању девиза. Када читате извештаје са разних међународних конгреса, сваки час видите како је неки наш делегат предложио да се идући конгрес одржи у Југославији. А један конгрес, таман и најскромнији, кошта око 10 милиона динара. ${ }^{10}$

Примећивао је да се ови скупови „стихијски рађају, приређују их саме установе“, а требало би да буду искључиво у надлежности Савета академија. ${ }^{11}$ Осим тога, Андрић се противио да се научници и уметници из иностранства доводе у Југославију тако што им се плаћају сви трошкови боравка. Сматрао је да је то не само финансијско оптерећење, већ и нека врста понижења, јер „странци стичу утисак да смо тако изоловани да треба по сваку цену да нам неко долази“.12

Кад је о академијској сарадњи са иностранством реч, управо је Андрић у Савету академија био за то задужен. Био је од стране Савета овлашћен да припреми „реферат о регулисању питања одашиљања наших делегата у иностранство. “13 То је било нарочито осетљиво питање, пошто су многи академици свих трију академија били још увек перципирани ако не као „народни непријатељи“, а оно као „непоуздани“. Залагао се - и у томе имао свесрдну Крлежину подршку - да Савет има апсолутно коначну реч у одлуци ко може путовати у иностранство, а да појединачне академије само шаљу предлоге. Слагао се Андрић и са Крлежиним примедбама

10 АJ 55-6-33 (30. октобар 1954).

11 АЈ 55-3-21 (23. и 24. фебруар 1951).

12 АЈ 55-3-20 (19. и 20. јануар 1950). Крлежа је, одбијајући оптужбе на свој и Андрићев рачун, да су „нетолерантни и затворени у своје зидове“, истицао да је „опћи ниво свих наших тзв. интелектуалних скупова управо мизеран“. АЈ 55-3-21 (23. и 24. фебруар 1951).

13 АJ 55-2-14 (17. и 18. новембар 1948). 
на понашање југословенских научника у иностранству, ${ }^{14}$ те протестовао када би неко ко није стручњак за одређену област ишао на конгрес. Конкретно је замерао што је на византолошки конгрес Југославенска академија знаности и умјетности послала сликара Крсту Хегедушића. ${ }^{15}$ Такође је упозоравао на непропорционалан однос природних и хуманистичких наука, односно на то да, када су у питању одласци на семинаре и конгресе у иностранство, академије фаворизују природне науке. ${ }^{16}$ Зато је Андрић - чини се с правом - сматрао „да су данас студијски боравци у иностранству много потребнији научницима од конгреса“. 17

Посебно оштар и непомирљив Андрић је био у залагању да академије коначно постану, поред научних, и у правом смислу те речи уметничке. Број уметника (књижевника, ликовних уметника, музичких уметника) био је у тим годинама после Другог светског рата стварно занемарљив. А и када су примани у неку од академија, отпор је био страховит (најбољи пример за то је пријем Бранислава Нушића у тадашњу Српску краљевску академију). У свом залагању за бољи третман уметника, Андрић је имао здушну Крлежину подршку. Као једина два књижевника међу члановима Савета академије, они су наступали са свешћу о потреби рушења академске конзервативности, оштро се борећи за сопствени еснаф. Андрић је инсистирао да републичке академије „широм отворе врата уметницима“, и тако, како је Крлежа истицао, „оправдају своје називе“. Но, једна од тих академија није, што се назива тиче, имала шта да оправда, и Андрић је стално указивао на то да једино српска академија у свом имену нема одређење уметности. Андрић је, уопште, посебно критичан био према својој академији наука, па је са

14 Указивао је, наиме, Крлежа „да неки одлазе са својим женама и троше велике своте новца, да ступају у везу са емигрантским групама и делују у извесном смислу негативно, да држе предавања која у аудиторијуму изазивају веселост - све то значи с једне стране бламажу, а с друге стране негативну политичку пропаганду“. АJ 553-19 (27. и 28. новембар 1950).

15 АJ 55-3-20 (19. и 20. јануар 1951).

16 AJ 55-7-40 (7. и 8. јун 1957).

17 АЈ 55-4-26 (27. и 28. јун 1952). 
горчином указивао како „у Српској академији наука књижевност има један мало полулегитиман статус; она је на леву руку ту прикључена“. ${ }^{18}$ Овим је потврђена Андрићева опаска изречена више од три године раније: „Налазим да ћемо још дуго времена остати ограничени само на науку“. 19

С друге стране, како су године пролазиле, а у уметности ce, а напосле књижевности - у светлу опште демократизације друштва - почеле испољавати модернистичке тенденције, Андрић је наступао са прилично конзервативних становишта. Више пута је и у дискусијама на седницама Савета академија указивао на то да Савет мора да реагује бар својим мишљењем када су у питању нове уметничке тенденције, налазећи да „уметничка делатност у земљи је анархична“. ${ }^{20}$ Ово је изречено 1954. године, дакле у време када је јачао модернизам у књижевности и ликовној уметности и када се, рецимо, увелико припремало покретање модернистичког часописа, који ће изаћи већ почетком 1955. године. Биће то Дело.

А кад је о науци реч, и ту је Андрић имао понешто да каже, али је долазио у сукоб са научним радницима у Савету академија. Као књижевник, и човек опште културе, имао је примедбе на, како је говорио, „сувише уситњен“ рад на науци. Залагао се за широке и обухватне студије, за синтетичке радове и велика, сводна истраживања. Истицао је да Савет академија, „и морално и финансијски“, треба да охрабрује „велике синтезе на живе теме - да не потрошимо наш углед и нашу енергију на све и свашта“. Ту му је оштро и бескомпромисно реплицирао Александар Белић, истичући да „сви ти наизглед ситни радови доприносе стварању слике о нашој прошлости“, а онда прилично иронично упитао Андирћа откуд њему сва она знања о прошлости која је уткао у своје романе. ${ }^{21}$

Стицајем околности, Иво Андрић је председавао бурним састанком Савета академија одржаном 19. и 20. децембра 1952. године у Загребу. На овом састанку покренуло

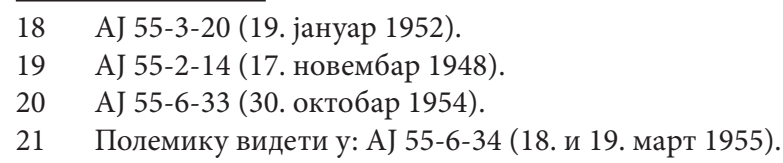


се, а поводом припреме за штампу Билтена Савета академија, питање о називу Југославенске академије знаности и умјетности у Загребу. Година је то када су почели да дувају неки нови ветрови у науци и култури. Крлежа је већ одржао знаменити реферат на Конгресу Савеза књижевника Југославије, а дестаљинизација је већ добрано одмакла. У том светлу, а још увек у нади да ће Савет академија прерасти у једну централну, југословенску академију, делегати Српске академије наука, а посебно Александар Белић и Иво Андрић, заложили су се да се Југославенској академији у Загребу име промени у Хрватска академија знаности и умјетности. Овај смео - и судећи према реакцијама делегата саме ЈАЗУ изненађујући - предлог наишао је на отпор. Све је почело са Крлежиним протестом што је Синиша Станковић у Билтену Савета академија у француском преводу ЈАЗУ назвао Academie Croate nomée „Yougoslave“ (Хрватска академија звана „Југословенска“). Делегати САН били су одлучни у ставу да ЈАЗУ никако, осим по називу, „не може бити југословенска академија, јер није надлежна за целу територију Југославије“. На то је реплицирао Крлежа:

У оном тренутку када је ова академија у Загребу била југославенска, онда још ни једне суверене балканске државе није било. Турци су били на обали Саве. Ако ми тај факат износимо пред иностранство, онда ми не можемо оно „Yougoslave“ да стављамо под наводнике. То изгледа као да се ставља у питање југославенство ове Академије, а то се не смије, јер она од свога југославенства никада није хтјела да одступа.

Крлежа је чак натукнуо да стављање имена „југословенска“ под наводнике може да се схвати као иронија. У целој овој полемици, Андрић се, као председавајући, држао доста повучено, позивајући да се о свему разложно промисли, те да се најпре разговара о именовању у Билтену, а „о оном другом не вреди дискутовати“. Иако је, дакле, и сам био на становишту да се ЈАЗУ додели назив Хрватске академије, био је свестан - и то је у једном тренутку нагласио - да је то, пре свега, политичко питање, које је уз то оптерећено и хипотеком из блиске прошлости. Он је подсетио да је име 
ЈАЗУ промењено у Независној држави Хрватској и упозорио: „Да је овако штампано, Савет академија би био политички нападнут“. Крлежа, међутим, није одустајао, тврдећи да је ЈАЗУ „дакако хрватска“, али да је у оно време када је основана била заправо југословенска, јер остали јужнословенски народи нису имали својих академија, а имала је, и има, у своме чланству и Србе и Бугаре. Видело се, заправо, да Крлежа не жели да се ЈАЗУ оспори „право идејне зачетнице југославенства“, што је Андрић подржао, али ипак наглашавајући да ће странцима бити јасније ако се у Билтену на француском језику ЈАЗУ назове хрватском академијом, без онога „југословенска“ под наводницима. Као што је познато, све до распада земље име ЈАЗУ остаће непромењено. ${ }^{22}$

У низу других иступања Андрића као члана Савета академија ФНРЈ, може бити занимљиво оно које се тицало тзв. језичке политике, а пре свега терминолошких питања. Наиме, један од задатака Савета академија било је усклађивање стручних термина за одређене области, ради уједначавања научне терминологије. Андрић се, као и у другим стварима, залагао да се иде ка потпуном уједначавању, без обзира на дотадашње важеће појмове. Истицао је, притом, да је међусобни утицај српских и хрватских језичких идиома, па чак и словеначког и српскохрватског језика, у одређеним струкама неминован, и да га треба прихватати. Како је ово вредно сведочанство о Андрићевим размишљањима о језику, вреди његову дискусију навести у целини:

Постоје заједничке ствари о којима не треба само да измењујемо своје мисли, него и да сам посао заједнички вршимо. На пример, измена језика. У Београду се, на пример, сада води акција за исправљање језика, термина, парола и свега онога што не спада у наш језик и где има много чудовишних ствари. ${ }^{23}$ Разумљиво је, ту је мало тешко повући линију између српског и хрватског језика. Овде се предвиђа извесна терминологија, предвиђено је суделовање Армије у

22 Сви наводи према: АJ 55-5-27 (19. и 20. децембар 1952).

23 Радило се, заправо, о акцији која је била иницирана раскидом са СССР-ом. Ишло се на то да се политичка и стручна терминологија ослободи русизама и совјетских термина. 
том раду, а тешко је тај рад замислити не само без суделовања Хрвата, него и Словенаца. На пример, у питању спорта ми смо узели словенску /словеначку; прим. Б. Ђ./ номенклатуру. Нисмо нити приметили када је до тога дошло. Пре тридесетак година нико није знао шта је то смук и смучке, али данас нико код нас не каже скијање, већ смо узели словенске речи. Затим, на пример, реч пршић, итд. То је наједанпут дошло само по себи. Тиме хоћу само да кажем да има ту ствари на које морамо обратити пажњу већ сада. Јер, ми не можемо направити терминологију, на пример, поморских назива, кад има и Словенаца, и Срба, и Хрвата на мору. Уосталом, доћи ће они и из Суботице и Панчева да буду морнари. ${ }^{24}$

Иво Андрић био је један од најагилнијих и најактивнијих чланова Савета академија, и као да је највише радио на томе да тај Савет задржи, па и прошири своје ингеренције. И овим деловањем потврђивао је своје југословенско политичко биће и своје схватање о потреби научног и културног јединства. Како је време одмицало, међутим, Савету академија све више су одузимане одређене надлежности, и он је од регулативног и контролног тела постајао координационо, а потом тек саветодавно тело. Растакање Савета академија тешко је падало Андрићу. Све време је, рецимо, покушавао да се надлежности Савета академија прошире и на разне институте и друге научне установе у земљи, ${ }^{25}$ али у томе није имао успеха. Но, док су други делегати који су од почетка били укључени у рад Савета постепено напуштали ту организацију (Крлежа крајем 1956. године), Андрић је још увек истрајавао у својим замислима, али углавном безуспешно. Савет академија дошао је у посебно незгодну ситуацију када је почетком 1958. године формиран Савезни савет за науку. Но, када су, одмах затим, формирани и републички савети за науку, Андрић је увидео процес разједињења у науци и искрено се тога плашио. Због тога је мислио да Савет академија треба да остане, макар као кохезиони фактор:

24 АЈ 55-2-16 (28. и 29. март 1949).

25 АЈ 55-5-29 (4. и 5. јун 1953). 
Ако се Савет угаси, постоји онда опасност да три академије оду свака на своју страну, а то не одговара ни нашој стварности ни општим тенденцијама целокупног државног живота. ${ }^{26}$

Међутим, пред Андрићевим очима рушило се заједништво, а академије преузимале дотад заједничке послове. Тако је заједнички рад на проучавању ономастике и топономастике, који је био у надлежности Савета академија, а који је отпочео Александар Белић, преузела ЈАЗУ, уз образложење Марка Костренчића да „ми имамо сва три дијалекта, па би JАЗУ све то могла повезати“.27

Па иако је понекад готово пркосно поручивао да је „важно да овај Савет постоји, а шта ће он радити - то је друга ствар, “28 Андрић је ипак могао само резигнирано да закључи:

Овај наш Савет је сада у једном прелазном стадијуму... Ми данас немамо више ни праве канцеларије. Ово је, уопште, једна установа у ликвидацији. ${ }^{29}$

Изгубивши, најзад, и сам вољу да се бори, као једини преостали члан Савета од оних који су га утемељили, Андрић је последњи пут председавао састанком Савета академија 22. децембра 1959. године у Београду, а одмах затим се и сам повукао. Савет академија наставио је да делује све до 1971. године, али као све мање важна и све мање уважавана међуакадемијска организација. Андрићева страховања су се обистинила. Ипак, његово деловање у Савету академија ФНРЈ, које је потрајало више од деценије, још је једно сведочанство о његовом несебичном и активном друштвеном ангажману у социјалистичкој Југославији.

\section{ИЗВОРИ И ЛИТЕРАТУРА}

Архив Југославије, Фонд Савета академија наука и уметности ФНРЈ (СФРЈ)

\footnotetext{
26 АЈ 55-8-44 (5. јул 1958).

27 АЈ 55-8-44 (5. јул 1958).

28 AJ 55-8-46 (22. децембар 1959).

29 АJ 55-8-45 (17. фебруар 1959).
} 


\section{Bojan Đorđević}

\section{IVO ANDRIĆ IN THE COUNCIL OF ACADEMIES OF THE FEDERATIVE NATIONAL REPUBLIC OF YUGOSLAVIA}

\section{Resume}

In the years immediately after the Second World War, in the early period of socialist Yugoslavia, with centralist tendencies, the Yugoslav political top, specifically its part in education and culture, showed a desire to create central Yugoslav institutions of culture and science. In such an atmosphere, the idea of unifying the work of the three existing academies of science - the Yugoslav Academy of Science and Arts, the Serbian Academy of Sciences and the Academy of Sciences and Arts of Slovenia appeared. Thus, the Yugoslav Academic Council was created, which will be later known as the Council of Academies of the Federal People's Republic of Yugoslavia (later the Socialist Federal Republic of Yugoslavia), in which Ivo Andrić will play an important role over a decade. The paper deals with his work in the Council of academies and on the attitudes he has advocated. 